O PAPEL DO FISIOTERAPEUTA EM HOSPITAIS AO REDOR DO MUNDO: uso do linkedin como auxilio à pesquisa

\section{THE ROLE OF PHYSIOTHERAPIST IN HOSPITALS AROUND THE WORLD: use of linkedin as a support to research}

\author{
Leandro Blancato ${ }^{1}$ \\ Lara Jansiski Motta ${ }^{2}$
}

\begin{abstract}
Resumo
O presente estudo teve como objetivo determinar as diferenças e igualdades nas funções desempenhadas pelo fisioterapeuta hospitalar de diferentes países. Para isto, foi desenvolvido um questionário onde foram perguntadas quais intervenções os fisioterapeutas realizam em seu trabalho, este questionário foi distribuído por meio da mídia social Linkedin a profissionais de fisioterapia que exerciam a profissão em instituições hospitalares em todo o mundo. Ao todo, 185 fisioterapeutas responderam a pesquisa, e assim, constatou-se que existem diferenças importantes no papel desempenhado pelo fisioterapeuta de acordo com a sua localização, sendo as principais funções dos fisioterapeutas a prescrição de exercícios físicos e exercícios respiratórios.
\end{abstract}

Palavras-chave: Intervenções fisioterapêuticas. fisioterapia hospitalar. serviços de Saúde. web-survey.

\begin{abstract}
This study aimed to determine the differences and similarities in the functions performed by hospital physical therapists from different countries. For this, a questionnaire was developed, in which physiotherapists were asked which interventions they perform in their work, this questionnaire was distributed through the LinkedIn social network to physical therapy professionals who work in hospitals around the world. Altogether, 185 physical therapists answered the survey, and this way, it was found that there are important differences in the role performed by the physiotherapists according to their location, and the main functions of physiotherapists are the prescription of physical exercises and chest therapy.
\end{abstract}

Keywords: Hospital physiotherapy. health services. web-survey.

\footnotetext{
${ }^{1}$ Aluno do programa de Mestrado Profissional em Gestão em Sistemas de Saúde da UNINOVE

. E-mail: fisio.blancato@gmail.com

2 Professora no programa de Mestrado Profissional em Gestão em Sistemas de Saúde da UNINOVE e Doutora em Saúde Coletiva pela Universidade Federal de São Paulo (UNIFESP). E-mail: larajmotta@uni9.pro.br
}

Artigo recebido em: 04 de março de 2020. Artigo aceito em 07 de janeiro de 2021. 


\section{Introdução}

The physiotherapist is the professional who offers health services in order to maintain or recover the physical capacity, quality of life, psychological, emotional, social and physical well-being of individuals. Among their activities are the evaluation of the patient, the formulation of the diagnosis, the provision of consultation, the referral to other professionals and the prescription of autotherapy.(WORLD CONFEDERATION FOR PHYSICAL THERAPY, 2019)

Being one of the work objects of the physiotherapist, the hospitalized patient may present a decrease in physical and respiratory conditions, constituting the main treatment goals of the physiotherapist.(GOSSELINK et al., 2011)

However, the exact role of the physiotherapist is not clear, since this professional can perform different activities depending on the country that he is located. For example, airway suction is performed by physiotherapists in some countries while in others it is the competence of other professional classes.(MILLER et al., 2019)

An understanding of global physiotherapeutic practices is necessary, since this way, professional functions and procedures can be standardized and thus reinforce physical therapy practices worldwide. In addition, with globalization, people are constantly migrating around the world, and in this way, the present study can assist physical therapists in these conditions.

Therefore, this research aims to determine the similarities and differences in the functions performed by physiotherapists in hospitals in different countries.

\section{THEORETICAL BACKGROUND}

\section{The role of the physiotherapist at the hospital}

The physiotherapist works in different modes and in different sectors, accompanying the patient from admission until hospital discharge.(DABER; JACKSON, 1987) Most of the studies show the importance of physical therapy in the treatment of critically ill patients admitted in the Intensive Care Unit; however, the physiotherapist's work is also important in the wards,(SARKIES et al., 2018) trauma,(CALTHORPE et al., 2016) urgency and emergency,(BRUUN; NØRGAARD, 2014) and haemodialysis units.(BULCKAEN et al., 2011)

Within each of these units, the physiotherapist acts to prevent or improve muscle weakness, joint stiffness, functional capacity, atelectasis, airway clearance, which can 
decrease extubation failure and prevent orotracheal intubation.(GOSSELINK et al., 2011)

The physiotherapist's presence culminates in the rapid supply of devices, mobilization and an overview of the patient's physical capacity, in addition to the retransmission of information to the multidisciplinary team.(BRUUN; NØRGAARD, 2014)

One of the major functions of the physiotherapist is the prescription of physical exercises, also known as patient mobilization, composed of passive exercises, active exercises of limbs, resistance exercises, aerobic exercises, changes in positioning on the hospital bed, removal of the patient from the hospital bed, sitting the patient on the edge of the bed, standing and walking.(ENGEL et al., 2013; STILLER, 2000) Neuromuscular electrical stimulation (NMES) improves muscle strength in hospitalized patients.(SCHARDONG et al., 2017) Greening et al.,(2014) included NMES as part of the mobilization of participants in their research.

In this regard, chest therapy consists of several techniques, such as bronchial hygiene manoeuvres,(MCCOOL; ROSEN, 2006) pulmonary expansion manoeuvers,(LAWRENCE; CORNELL; SMETANA, 2006) respiratory muscle strengthening(MCCONNELL, 2013) and positive expiratory pressure therapy.(JOHNSTON; JAMES; MACKNEY, 2013)

Troosters et al.,(2015) suggest several skills that should be developed in respiratory physiotherapists, and in addition to those previously reported, the physiotherapist should be skilled in mechanical ventilation and non-invasive ventilation (NIV).

Airway management consists of tracheal intubation, tracheostomy, extubation, among others.(RUSSOTTO; MYATRA; LAFFEY, 2019) The respiratory therapist may be involved in managing the airways; (LUCISANO; TALBOT, 2012) however, it is still unclear whether the physiotherapist should perform orotracheal intubation and airway aspiration. Albeit, it is known that this professional can participate in the process of respiratory aid removal and extubation.(BACCI et al., 2019)

The transport of critically ill patients poses a risk to their lives, so there is a need for at least 2 people to perform this procedure, among them, there is the possibility of a respiratory physiotherapist,(WARREN et al., 2004) meaning another assignment for the physiotherapist. 
Likewise, ulcer pressure management is another important procedure in hospitalized patients, usually performed by the nursing team,(EBI; MENJ; HUNDE, 2017) and one of its treatments is the patient's movement routine, which can be included as part of the scope of the hospital physiotherapist.(STILLER, 2000)

\section{Use of social media in the research}

Conducting a study that evaluates and compares characteristics of different locations in the world requires contact with different people or institutions, which in most cases are sufficiently distant, making the research difficult to achieve. For this reason, several studies have been carried out through the internet, since online research has a lower cost, faster data collection speed, easy implementation, geographic and time flexibility, evaluation of sensitive and confidential topics, in addition to reaching a large and varied number of individuals.(CALLEGARO; MANFREDA; VEHOVAR, 2015; KAYAM; HIRSCH, 2012; KILINÇ; FIRAT, 2017)

Access to the diversity and numeracy of the sample of social medias allows the sampling error to be minimized, which is typical in face-to-face social studies.(KOSINSKI et al., 2015)

According to the opinion of experts, online data collection has a slight advantage

over face-to-face collection, especially with regard to the voluntarism of participants.(KILINÇ; FIRAT, 2017)

The main difficulty of surveys on the internet is the non-response of participants, because the invitation may not be delivered properly or the participants may refuse to respond.(COUPER, 2011) To solve this issue, offering rewards to participants, short and concise questions, sharing results with participants, explaining the purpose and importance of the study is suggested.(KILINÇ; FIRAT, 2017)

Facebook and Twitter are, among social networks, the most used in scientific research.(KAPOOR et al., 2018) Kosinski and his collaborators(2015) carried out several studies based on Facebook, reaching over 10 million participants, thus showing their feasibility, the opportunities and challenges of this type of research.

Kayam and Hirsch(2012) suggest spreading the research link on various social networks. The authors shared their research on Facebook, Twiter and Linkedin pages. They also counted on the help of several communities for dissemination, such as social, voluntary, municipal and community organizations, reaching 232 participants in 3 months. 
Unkelos-Shpigel, Sherman and Hadar(2015) opted for using the Linkedin social network to promote their study. The authors published the questionnaire link in 7 architecture groups on Linkedin and thus obtained 161 responses to the survey. In the end, they concluded that the use of the social network was viable.

It is also possible to use WhatsApp to aid in the dissemination and conduct of scientific research, as this is another online tool that has been proving viable in the execution of social studies.(TAVARES; SOBRAL; MOTTA, 2016)

\section{METHOD}

This research is a survey, because it identifies the work characteristics of the professional physiotherapist in different places through the opinion of the participants. It is also considered a quantitative study, because it enumerates the results in order to quantify the responses, which are analysed in a descriptive manner.

To achieve the objectives, a survey was carried out through an electronic questionnaire developed based on the literature review. By doing so, the physiotherapist's roles in the treatment of hospitalized patients were identified. In order to do so, the participants were asked about the role and functions of the physiotherapist in the treatment of patients admitted to the hospital where they worked.

\section{Questionnaire}

The questionnaire consisted of a single question, in which a list with several tasks was available (figure 1) and the respondents were asked to select which corresponded to their work routine.

\begin{tabular}{|ll|}
\hline 1 & Physical exercises \\
\hline 2 & Chest therapy \\
\hline 3 & Changes in patient positioning \\
\hline 4 & Non-invasive mechanical ventilation \\
\hline 5 & Settings and adjustment of mechanical ventilation parameters \\
\hline 6 & Ventilatory aid removal process \\
\hline 7 & Extubation \\
\hline 8 & Orotracheal intubation \\
\hline 9 & Airway suctioning \\
\hline 10 & Equipment hygiene \\
\hline 11 & Medication \\
\hline 12 & Assistance in intra-hospital transport of critically ill patients \\
\hline
\end{tabular}

Figure 1 - List of tasks and functions of the hospital physiotherapist available to the participants in the questionnaire

Source: prepared by the authors, 2020.

The questionnaire was developed electronically using the Google Forms tool, available at docs.google.com/forms, which consists of an online platform on which it is 
possible to develop different types of questions. Each form developed generates an individual link, enabling the distribution to several people in various places. In order to respond, the participant only needs to have access to the internet.

The collection period lasted three months. In addition, questionnaires were developed and made available in three languages: English, Spanish and Portuguese.

\section{Sample}

The sample was selected via Linkedin, as since it is a social media of a professional nature, it was possible to access the necessary data for specimen election, since the participants should necessarily be physical therapists who practiced the profession in hospital institutions.

The search for the sample was done using the search tool available on the Linkedin platform with the keywords "hospital" and "physiotherapist", using the search filter to show results only for people profiles.

The search filter for country selection was also used, in which a search was carried out for each of the 193 countries belonging to the UN (United Nations), in addition to the inclusion of ten other non-UN countries.

\section{Data collection}

Data collection took place through three phases (figure 2). In the first phase, the profile of all people listed in the search results was analysed individually, then, a connection request was sent to all those who met the inclusion criteria. This was necessary because Linkedin does not allow messages to be sent to people who are not part of your network.

In the second phase, invitations were distributed asking the professionals to participate in the research. Invitations were sent using the messaging tool available on Linkedin.

The invitation consisted of a brief presentation with the objectives of the study, an explanation of how to proceed to answer the questionnaire, approximate response time, privacy security and the availability of the link to access the questionnaire, ending with a greeting and presentation of the researchers and their respective institutions.

Finally, the third phase consisted of the filling out of the questionnaire by the research participants (figure 2). 
PHASE 1

\begin{tabular}{|cc|}
\hline Connection request & 1831 \\
\hline Invitation to research & \\
\hline & PHASE 2 \\
\hline Answers & \\
\hline
\end{tabular}

Figure 2 - Research phases.

\section{RESULTS}

A total of 575 invitations to the survey were sent, of which, 185 people completed the questionnaire, totaling $32.2 \%$ response rate. These results are compatible with those found by Cunningham et al.,(2015) who showed a 35\% response rate in an electronic survey with doctors and Shih and Fan(2008) who showed an average response rate of $34 \%$ for web searches.

The 185 responses came from 72 different countries, of which, the largest number of responses occurred by Brazilian physiotherapists. This can be explained, because the authors of this research are Brazilian and in some cases there was a network of contacts in common between them, facilitating the acceptance of the participants in the research. It is also possible to highlight a high number of responses from European countries, since among those with the greatest participation, were Greece, United Kingdom, Spain and Ireland (figure 3).

Figure 4 shows the general results of the research, making it possible to observe the main attributes of the physiotherapist in the hospital. Among the functions most highlighted by professionals are physical exercises and chest therapy, of which $100 \%$ and $88 \%$ of the participants reported to be their function, respectively.

All other activities were reported as part of the physiotherapist's routine by less than half of the participants, with emphasis on intubation and medication procedures, which 9 and $6 \%$ of participants perform, respectively (figure 4).

\begin{tabular}{|llll|ll|ll|}
\hline Country & N & Country & N & Country & N & Country & N \\
\hline Brazil & 16 & Egypt & 3 & Dominican Republic & 2 & Jordan & 1 \\
Greece & 7 & Kuwait & 3 & Taiwan & 2 & Maldives & 1 \\
United Kingdom & 7 & Mexico & 3 & Tanzania & 2 & Micronesia & 1 \\
Spain & 6 & Pakistan & 3 & Turkey & 2 & Nepal & 1 \\
Ireland & 6 & Kenya & 3 & Qatar & 1 & Oman & 1 \\
\hline
\end{tabular}

Revista Eletrônica Gestão e Serviços v.11, n. 2, pp.3150 - 3166, Julho/Dezembro 2020. ISSN Online: 2177-7284 e-mail: regs@,metodista.br 
BLANCATO; MOTTA

\begin{tabular}{|c|c|c|c|c|c|c|c|}
\hline Nigeria & 6 & Serbia & 3 & Singapore & 1 & Panama & 1 \\
\hline Argentina & 5 & Sri Lanka & 3 & South Korea & 1 & Paraguay & 1 \\
\hline Croatia & 5 & Saudi Arabia & 2 & Cuba & 1 & Peru & 1 \\
\hline United Arab Emirates & 5 & Australia & 2 & Denmark & 1 & Puerto Rico & 1 \\
\hline Ghana & 5 & Botswana & 2 & El Salvador & 1 & Romania & 1 \\
\hline India & 5 & Canada & 2 & Ecuador & 1 & Rwanda & 1 \\
\hline Ukraine & 5 & Chile & 2 & Slovenia & 1 & Swaziland & 1 \\
\hline Portugal & 4 & Ethiopia & 2 & United States & 1 & Sweden & 1 \\
\hline Czech republic & 4 & Finland & 2 & Fiji & 1 & Thailand & 1 \\
\hline South Africa & 3 & Japan & 2 & France & 1 & Uganda & 1 \\
\hline Albania & 3 & Macedonia & 2 & Gambia & 1 & Venezuela & 1 \\
\hline Bangladesh & 3 & Malaysia & 2 & Iran & 1 & & \\
\hline Colombia & 3 & Norway & 2 & Iceland & 1 & & \\
\hline Costa Rica & 3 & Papua New Guinea & 2 & Italy & 1 & & \\
\hline
\end{tabular}

Figure 3 - Number of questionnaires answered by country.

Source: Research data, 2020.

\section{DISCUSSION}

According to the results found in the research, the main role of the physiotherapist is the prescription of physical and respiratory exercises. This can be explained, because with them the physiotherapist's main objective is reached, which is to restore movement and functionality to the maximum.(WORLD CONFEDERATION FOR PHYSICAL THERAPY, 2019)

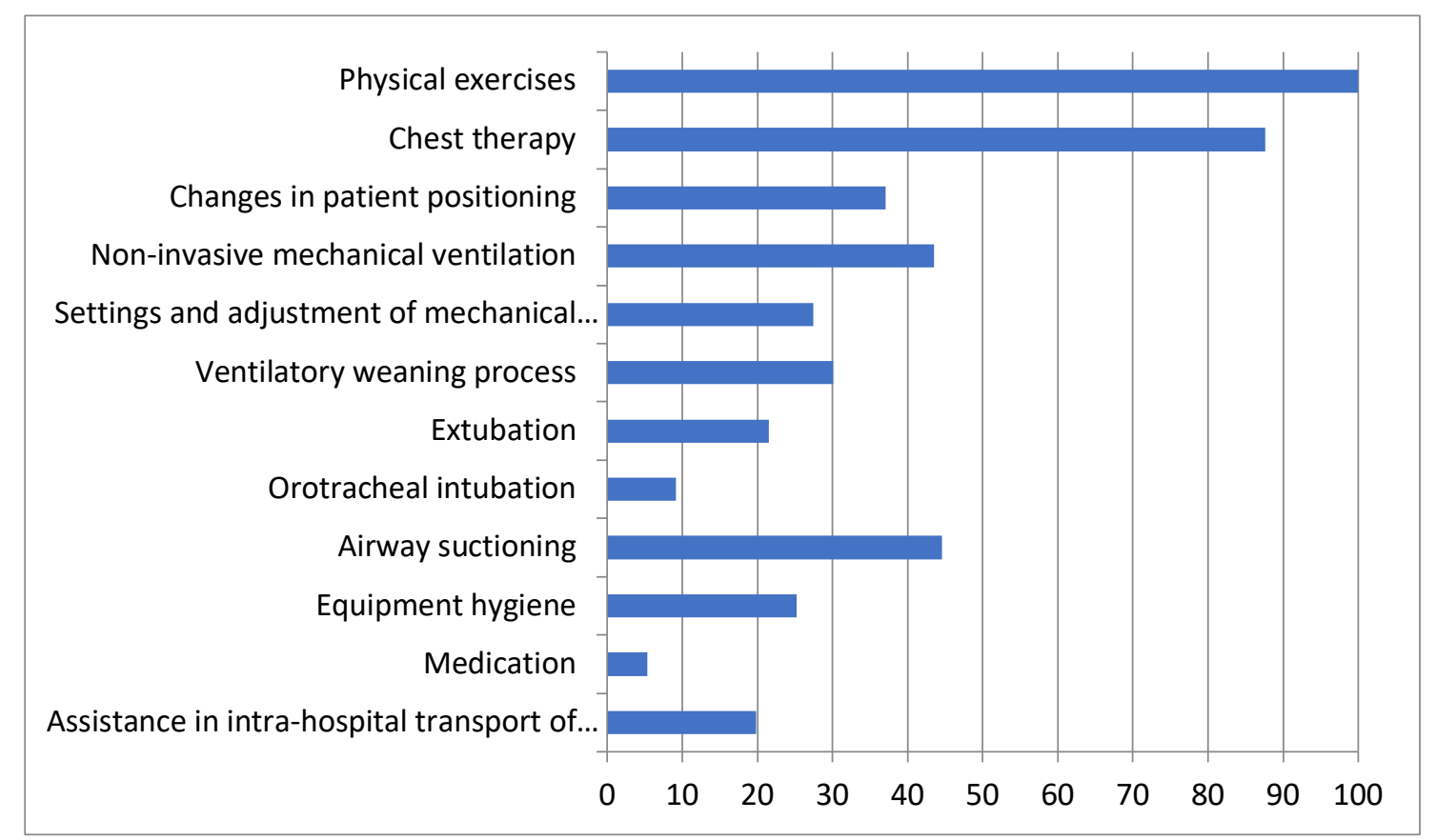

Figure 4 - Number of responses from participants regarding the physiotherapist's functions in the hospital (\%).

Studies show the importance of physical exercises in hospitalized patients, which should be started as soon as possible, which can lead to a reduction in 
hospitalization time, hospital costs and less complications related to the patient's stay.(LI et al., 2013; LORD et al., 2013)

Other studies reveal chest therapy as the role of the physiotherapist; however, there is little evidence that this therapy improves the patient's clinical condition.(FLENADY; GRAY, 2002; YANG et al., 2013) This may justify why, despite the high rate, it was not $100 \%$ of the participants who reported this task as part of their work routine.

Airway management is a delicate procedure that can put the patient at risk; therefore, it seems to be the doctor's exclusive procedure. The American Society of Anaesthesiology is concerned with other professionals practicing respiratory care, but accepts that a properly trained respiratory therapist can perform such care.(AMERICAN SOCIETY OF ANESTHESIOLOGISTS, 2018) This may explain why it was one of the functions least performed by the participants.

In some countries, such as the Czech Republic, the administration of medicine may be the responsibility of several health professionals;(HECZKOVÁ; BULAVA, 2016) however, in general, it seems to be a service targeted to nursing professionals.(BHOWMIK, 2015; SHERRIFF; WALLIS; BURSTON, 2011)

Likewise, airway aspiration is usually performed by the nursing team, but in some countries like Brazil it is performed by the physiotherapist,(MILLER et al., 2019) meeting the results presented in this study, from which it was found that this procedure is performed by almost half of the research participants.

Table 1 shows the survey data grouped according to the continent where the participants worked. The data is shown in absolute values and in percentages, and in this way it is possible to notice that the aspiration of airways is a competence mainly of physiotherapists in Latin America, since $80 \%$ of them say to perform this task in their daily work. In Africa and Oceania, this procedure is also widely performed, cited by a total of $55 \%$ and $50 \%$ of physical therapists respectively.

Similarly, NIV is managed by most physiotherapists in hospitals of South America and by about half of physiotherapists in Africa and Europe. This finding is in line with what was stated by Nicolini, Piroddi and Barlascini,(2015) who demonstrate that NIV can be administered by doctors, nurses or physiotherapists depending on the country.

In relation to invasive mechanical ventilation, this care is performed by the 
physiotherapist mainly in South America. In other continents, the number of physiotherapists who perform this work is small, reaching zero in North and Central America (table 1). Even with these results, it is believed that the physiotherapist with respiratory knowledge is qualified and should, whenever necessary, operate and monitor the mechanical ventilation device.(DABER; JACKSON, 1987; GOGNIAT et al., 2019)

The respiratory aid removal process and extubation follow the same trend as the other tasks presented, the majority of physiotherapists in South America (77\%) perform this procedure in their work routine, in line with that shown by some authors.(BACCl et al., 2019; PIOTTO et al., 2011) However, in other continents a small minority does it.

On Table 1, it is also possible to note that $20 \%$ of the physical therapists participating in the survey reported accompanying the critical patient in intra-hospital transport as being one of the least performed functions by them. Some authors suggest the involvement of the multidisciplinary team in this task,(CHANG et al., 2019; WARREN et al., 2004) and among them may be the physiotherapist; however, according to Bergman et al.,(2019) the nurse is primarily responsible for transporting the critical patient. 
Table 1 - Results of the survey presented per continents

\begin{tabular}{|c|c|c|c|c|c|c|c|c|c|c|c|c|c|c|c|c|c|c|c|c|c|c|c|c|c|}
\hline \multirow[t]{2}{*}{ Continent } & \multirow[t]{2}{*}{ Answers } & \multicolumn{2}{|l|}{$\mathbf{P E}$} & \multicolumn{2}{|l|}{ CT } & \multicolumn{2}{|c|}{ CPP } & \multicolumn{2}{|c|}{ NIV } & \multicolumn{2}{|c|}{ MV } & \multicolumn{2}{|c|}{ VWP } & \multicolumn{2}{|l|}{ EX } & \multicolumn{2}{|l|}{ OI } & \multicolumn{2}{|l|}{ AS } & \multicolumn{2}{|c|}{ EH } & \multicolumn{2}{|c|}{ ME } & \multicolumn{2}{|c|}{ CPT } \\
\hline & & $\mathrm{F}$ & $\%$ & $\mathrm{~F}$ & $\%$ & $\mathrm{~F}$ & $\%$ & $\mathrm{~F}$ & $\%$ & $\mathrm{~F}$ & $\%$ & $\mathrm{~F}$ & $\%$ & $\mathrm{~F}$ & $\%$ & $\mathrm{~F}$ & $\%$ & $\mathrm{~F}$ & $\%$ & $\mathrm{~F}$ & $\%$ & $\mathrm{~F}$ & $\%$ & $\mathrm{~F}$ & $\%$ \\
\hline Africa & 29 & 29 & 100 & 29 & 100 & 11 & 38 & 13 & 45 & 6 & 21 & 10 & 34 & 6 & 21 & 2 & 7 & 16 & 55 & 8 & 28 & 2 & 7 & 7 & 24 \\
\hline Asia & 39 & 39 & 100 & 29 & 74 & 9 & 23 & 11 & 28 & 6 & 15 & 6 & 15 & 3 & 8 & 3 & 8 & 15 & 38 & 15 & 38 & 4 & 10 & 5 & 13 \\
\hline Central America & 9 & 9 & 100 & 7 & 78 & 7 & 78 & - & - & - & - & - & - & - & - & - & - & 1 & 11 & 1 & 11 & - & - & 1 & 11 \\
\hline North America & 6 & 6 & 100 & 5 & 83 & 2 & 33 & - & - & - & - & - & - & - & - & - & - & 1 & 17 & - & - & - & - & - & - \\
\hline South America & 30 & 30 & 100 & 26 & 87 & 13 & 43 & 26 & 87 & 25 & 83 & 23 & 77 & 23 & 77 & 9 & 30 & 24 & 80 & 3 & 10 & - & - & 13 & 43 \\
\hline Europe & 66 & 66 & 100 & 62 & 94 & 26 & 39 & 30 & 45 & 14 & 21 & 15 & 23 & 8 & 12 & 3 & 5 & 23 & 35 & 20 & 30 & 5 & 8 & 10 & 15 \\
\hline Oceania & 6 & 6 & 100 & 5 & 83 & 1 & 17 & 1 & 17 & 1 & 17 & 2 & 33 & 1 & 17 & - & - & 3 & 50 & 1 & 17 & - & - & 1 & 17 \\
\hline Total & 185 & 185 & 100 & 163 & 88 & 69 & 37 & 81 & 44 & 52 & 28 & 56 & 30 & 41 & 22 & 17 & 9 & 83 & 45 & 48 & 26 & 11 & 6 & 37 & 20 \\
\hline
\end{tabular}

PE: Physical Exercises; CT: Chest Therapy; CPP: Changes in Patient Positioning; NIV: Non-Invasive Ventilation; MV: Settings and Adjustment of Mechanical Ventilation parameters; VWP: Ventilatory Aid Removal Process; EX: Extubation; OI: Orotracheal Intubation; AS: Airway Suctioning; EH: Equipment Hygiene; ME: Medication; CPT: Critically ill Patients Transport.

Source: Research data, 2020. 
The cleaning of equipment can decrease the rate of infection, a procedure,(RAMPLING et al., 2001) in general, performed by a specific hygiene team, and although there are no scientific reports of participation in this task, the physiotherapist is involved in the calibration and maintenance of equipment in the hospital.(GOGNIAT et al., 2019) This may explain why $17 \%$ of the physiotherapists who answered the questionnaire claim to perform this role.

The findings of this research indicate that the physiotherapist can perform different functions within the hospital according to the country or region that the professional is. This fact suggests a lack of criteria regarding the regulation of the profession and an excess of activities, which may, in some places, result in overwork for these professionals.

According to Klappa et al.,(2015) physiotherapists around the world feel overwhelmed, due to high demand, lack of time and resources, and thus, they were frustrated by not meeting the needs of patients.

Zanni et al.,(2010) showed that the unavailability of physiotherapists was an important factor for patients' complications, resulting in decreased strength, range of motion and functionality. A study with similar results showed that the main difficulties in accomplishment patient mobilization were the unavailability of the physiotherapist and the lack of time.(FONTELA; FORGIARINI JR.; FRIEDMAN, 2018)

In the opposite direction, Hoyer et al.,(2015) showed that American physiotherapists did not have time problems to execute the patient's mobilization. This finding is reinforced by the results shown here, as North American physiotherapists reported having fewer tasks in their daily work.

With this in mind, reducing the number of tasks can be a strategy for the physiotherapist to perform his main functions effectively. This is possible by distributing some physiotherapist tasks to other trained professionals.

The University of Iowa has developed the Center for Nursing Classification and Clinical Effectiveness with the aim of continually developing the NIC (Nursing Interventions Classification). The NIC is a detailed guide that identifies the treatments offered by nursing, organizes this information in a coherent and structured way, and provides a multidisciplinary communication language.(BUTCHER et al., 2018)

The NIC has proven to be an efficient and widely used tool in the assessment of nursing workload.(CRUZ et al., 2014) However, there is a lack of such a guide on 
physical therapy work. WCPT(WORLD CONFEDERATION FOR PHYSICAL THERAPY, 2019) discusses the physiotherapist's interventions, however, it does not describe these activities in detail, besides, it defends that the physiotherapist himself is responsible for determining his role and the objectives of his professional practice, as long as in accordance with the international guidelines.

\section{FINAL CONSIDERATIONS}

With the results obtained in this research, it was possible to identify the role of the physiotherapist that works in hospital organizations and thus the objective was reached, which was to determine the differences and similarities of the functions of this professional worldwide. In this way, it was observed that the main functions of physical therapists in the world are the application of physical and chest exercises, and that all other activities questioned were performed by less than half of the physiotherapists participating in the study.

One can conclude, then, that the physiotherapist can be in charge of different functions depending on the country in which he is working. The ideal scenario is the one in which the physiotherapist has an equal role in all countries, which strengthens professional practice, helps the development and application of scientific studies and provides integration between physiotherapists from different countries.

Despite reaching 185 responses, this number of participants is small considering the world population of physical therapists. Some countries had only one participant, so it is not possible to infer their answer represents the entire population of that country.

It is suggested to deepen this theme, taking into account other factors such as the characteristics of the hospital and the patient. In addition, it is necessary to develop a detailed guide that describes the role of the physiotherapist and the interventions performed by him.

\section{REFERENCES}

AMERICAN SOCIETY OF ANESTHESIOLOGISTS. Statement of Support for Respiratory therapists (RTs), Washington, p. 1, October, 17 of 2018. Disponível em: $<$ https://www.asahq.org/standards-and-guidelines/statement-of-support-for-respiratorytherapists-rts>. Acesso em: 31 out. 2019.

BACCI, S. L. L. DOS S. et al. Role of physical therapists in the weaning and extubation procedures of pediatric and neonatal intensive care units: a survey. Brazilian Journal of Physical Therapy, v. 23, n. 4, p. 317-323, 1 jul. 2019. 
BERGMAN, L. et al. Improving quality and safety during intrahospital transport of critically ill patients: A critical incident study. Australian Critical Care, v. 33, n.1, p. 12-19, jan. 2019.

BHOWMIK, S. R. Essential Nursing Competencies and its Learning Activities. Indian Journal of Surgical Nursing, v. 4, n. 3, sep-dec. 2015.

BRUUN, I. H.; NØRGAARD, B. Occupational therapy and physiotherapy benefit the acute patient pathway: A mixed-methods study. Journal of Nursing Education and Practice, v. 4, n. 4, p. 172, 5 mar. 2014.

BULCKAEN, M. et al. Implementation of exercise training programs in a hemodialysis unit: effects on physical performance. Journal of Nephrology, v. 24, n. 6, p. 790-797, dez. 2011.

BUTCHER, H. K. et al. Nursing Interventions Classification (NIC) - E-Book. Kidlington: Elsevier Health Sciences, 2018. 520 p.

CAlleGARO, M.; MANFREDA, K. L.; VEHOVAR, V. Web Survey Methodology. Londo: SAGE, 2015. 345 p.

CALTHORPE, S. et al. A benchmarking project of physiotherapy in Australian and New Zealand adult major trauma services. New Zealand Journal of Physiotherapy, v. 44, n. 3, 2016.

CHANG, Y.-C. et al. An interprofessional training program for intrahospital transport of critically ill patients: model build-up and assessment. Journal of interprofessional care, p. 1-5, 2019.

COUPER, M. P. Web survey methodology: Interface design, sampling and statistical inference. San Sebastián: EUSTAT, 2011. 58 p. Disponível em:

$<$ http://www.eustat.eus/productosServicios/datos/Seminario_53.pdf $>$. Acesso em: 29 jul. 2019.

CRUZ, C. W. M. DA et al. The Use of Nursing Interventions Classification (NIC) in Identifying the Workload of Nursing: An Integrative Review. International Journal of Nursing Knowledge, v. 25, n. 3, p. 154-160, 2014.

CUNNINGHAM, C. T. et al. Exploring physician specialist response rates to web-based surveys. BMC Medical Research Methodology, v. 15, n. 1, p. 32, 9 abr. 2015.

DABER, S. E.; JACKSON, S. E. Role of the physiotherapist in the intensive care unit. Intensive Care Nursing, v. 3, n. 4, p. 165-171, 1 jan. 1987.

EBI, W. E.; MENJI, Z. A.; HUNDE, B. M. Nurses' knowledge and Perceived Barriers About Pressure Ulcer Prevention for Admitted Patients in Public Hospitals in Addis Ababa, Ethiopia. American Journal of Internal Medicine, v. 5, n. 4-1, p. 1-6, 2017.

ENGEL, H. J. et al. Physical therapist-established intensive care unit early mobilization program: quality improvement project for critical care at the University of California San Francisco Medical Center. Physical Therapy, v. 93, n. 7, p. 975-985, 1 jul. 2013.

FLENADY, V.; GRAY, P. H. Chest physiotherapy for preventing morbidity in babies being extubated from mechanical ventilation. Cochrane Database of Systematic Reviews, n. 2, 2002. Disponível em: $<$ https://www.cochranelibrary.com/cdsr/doi/10.1002/14651858.CD000283/full?highligh 
tAbstract=withdrawn\%7Cphysical\%7Cphysic\%7Ctherapy\%7Ctherapi $>$. Acesso em: 29 out. 2019.

FONTELA, P. C.; FORGIARINI JR., L. A.; FRIEDMAN, G. Clinical attitudes and perceived barriers to early mobilization of critically ill patients in adult intensive care units. Revista Brasileira de Terapia Intensiva, v. 30, n. 2, p. 187-194, 2018.

GOGNIAT, E. et al. Definición del rol y las competencias del kinesiólogo en la unidad de cuidados intensivos. Revista Argentina De Terapia Intensiva, v. 35, n. 4, 2 jan. 2019. Disponível em: <http://revista.sati.org.ar/index.php/MI/article/view/592>. Acesso em: 2 nov. 2019.

GOSSELINK, R. et al. Physiotherapy in the intensive care unit. Neth J Crit Care, v. 15, n. 2, p. 66-75, 2011.

GREENING, N. J. et al. An early rehabilitation intervention to enhance recovery during hospital admission for an exacerbation of chronic respiratory disease: randomised controlled trial. BMJ, v. 349, p. g4315, 8 jul. 2014.

HECZKOVÁ, J.; BULAVA, A. The role of nurses in medication management in the Czech Republic: A narrative literature review. Elektronický, Recenzovaný, VedeckoOdborný Časopis, p. 38, 2016.

HOYER, E. et al. Barriers to early mobility of hospitalized general medicine patients: survey development and results. American Journal of Physical Medicine \& Rehabilitation, v. 94, n. 4, p. 304-312, 1 abr. 2015.

JOHNSTON, C. L.; JAMES, R.; MACKNEY, J. H. The current use of positive expiratory pressure (PEP) therapy by public hospital physiotherapists in New South Wales. New Zealand Journal Of Physiotherapy, v. 41, n. 3, p. 88-93, 2013.

KAPOOR, K. K. et al. Advances in social media research: past, present and future. Information Systems Frontiers, v. 20, n. 3, p. 531-558, 1 jun. 2018.

KAYAM, O.; HIRSCH, T. Using social media networks to conduct questionnaire based research in social studies case study: family language policy. Journal of Sociological Research, v. 3, n. 2, p. 57-67, 2012.

KILINÇ, H.; FIRAT, M. Opinions of expert academicians on online data collection and voluntary participation in social sciences research. Educational Sciences: Theory $\&$ Practice, v. 17, n. 5, 2017.

KLAPPA, S. G. et al. Compassion fatigue among physiotherapist and physical therapists around the world. Health Education, v. 3, n. 5, p. 124-137, 2015.

KOSINSKI, M. et al. Facebook as a research tool for the social sciences: Opportunities, challenges, ethical considerations, and practical guidelines. The American Psychologist, v. 70, n. 6, p. 543-556, set. 2015.

LAWRENCE, V. A.; CORNELL, J. E.; SMETANA, G. W. Strategies to reduce postoperative pulmonary complications after noncardiothoracic surgery: systematic review for the American College of Physicians. Annals of Internal Medicine, v. 144, n. 8 , p. 596, 18 abr. 2006.

LI, Z. et al. Active mobilization for mechanically ventilated patients: A systematic review. Archives of Physical Medicine and Rehabilitation, v. 94, n. 3, p. 551-561, 1 mar. 2013.

Revista Eletrônica Gestão e Serviços v.11, n. 2, pp.3150 - 3166, Julho/Dezembro 2020. ISSN Online: 2177-7284 e-mail: regs@metodista.br 
LORD, R. et al. ICU early physical rehabilitation programs: financial modeling of cost savings. Critical Care Medicine, v. 41, n. 3, p. 717-724, 1 mar. 2013.

LUCISANO, K. E.; TALBOT, L. A. Simulation training for advanced airway management for anesthesia and other healthcare providers: a systematic review. Aana j, v. 80, n. 1, p. 25-31, 2012.

MCCONNELL, A. Respiratory Muscle Training: Theory and Practice. [S.1.]: Elsevier Health Sciences, 2013.

MCCOOL, F. D.; ROSEN, M. J. Nonpharmacologic airway clearance therapies: ACCP evidence-based clinical practice guidelines. CHEST, v. 129, n. 1, p. 250S-259S, 1 jan. 2006.

MILLER, E. K. et al. Assessing the Clinical Competence of Health Care Professionals Who Perform Airway Suctioning in Adults. Respiratory Care, v. 64, n. 7, p. 844-854, 1 jul. 2019.

NICOLINI, A.; PIRODDI, I. M. G.; BARLASCINI, C. How to enhance experience and skill of non invasive ventilation: suggestions from the literature. Shortness Breath, v. 4, n. 1, p. 19-25, 2015.

PIOTTO, R. F. et al. Effects of the use of mechanical ventilation weaning protocol in the Coronary Care Unit: randomized study. Brazilian Journal of Cardiovascular Surgery, v. 26, n. 2, p. 213-221, jun. 2011.

RAMPLING, A. et al. Evidence that hospital hygiene is important in the control of methicillin-resistant Staphylococcus aureus. Journal of Hospital Infection, v. 49, n. 2, p. 109-116, 1 out. 2001.

RUSSOTTO, V.; MYATRA, S. N.; LAFFEY, J. G. What's new in airway management of the critically ill. Intensive Care Medicine, v. 45, n. 11, p. 1615-1618, 1 nov. 2019.

SARKIES, M. N. et al. Additional weekend allied health services reduce length of stay in subacute rehabilitation wards but their effectiveness and cost-effectiveness are unclear in acute general medical and surgical hospital wards: a systematic review.

Journal of Physiotherapy, v. 64, n. 3, p. 142-158, 1 jul. 2018.

SCHARDONG, J. et al. Functional electrical stimulation improves muscle strength and endurance in patients after cardiac surgery: a randomized controlled trial. Brazilian Journal of Physical Therapy, v. 21, n. 4, p. 268-273, 1 jul. 2017.

SHERRIFF, K.; WALLIS, M.; BURSTON, S. Medication calculation competencies for registered nurses: a literature review. Australian Journal of Advanced Nursing, v. 28, n. 4, p. 75-83, 2011.

SHIH, T.-H.; FAN, X. Comparing Response Rates from Web and Mail Surveys: A Meta-Analysis. Field Methods, v. 20, n. 3, p. 249-271, 1 ago. 2008.

STILLER, K. Physiotherapy in Intensive care: towards an evidence-based practice. Critical Care Reviews, v. 118, p. 1801-1813, 2000.

TAVARES, A. R. P. G.; SOBRAL, A. P. T.; MOTTA, L. J. Uso de la aplicación WhatsApp por estudiantes de Odontología de Sao Paulo, Brasil. Revista Cubana de Información en Ciencias de la Salud, v. 27, n. 4, p. 503-514, dez. 2016. 
TROOSTERS, T. et al. Development of a syllabus for postgraduate respiratory physiotherapy education: the Respiratory Physiotherapy HERMES project. European Respiratory Journal, v. 45, n. 5, p. 1221-1223, 1 maio 2015.

UNKELOS-SHPIGEL, N.; SHERMAN, S.; HADAR, I. Finding the missing link to industry: LinkedIn professional groups as facilitators of empirical research. 2015, [S.1.]: IEEE Press, 2015. p. 43-46.

WARREN, J. et al. Guidelines for the inter- and intrahospital transport of critically ill patients. Critical Care Medicine, v. 32, n. 1, p. 256-262, jan. 2004.

WORLD CONFEDERATION FOR PHYSICAL THERAPY. Policy statement: Description of physical therapy. . [S.1.]: World Confederation for Physical Therapy. Disponível em:

$<$ https://www.wcpt.org/sites/wcpt.org/files/files/resources/policies/2017/PS_Description _of_physical_therapy_FINAL.pdf>. Acesso em: 16 jul. 2019., 2019

YANG, M. et al. Chest physiotherapy for pneumonia in adults. Cochrane Database of Systematic Reviews, n. 2, 2013. Disponível em:

$<$ https://www.cochranelibrary.com/cdsr/doi/10.1002/14651858.CD006338.pub3/full/pt >. Acesso em: 29 out. 2019.

ZANNI, J. M. et al. Rehabilitation therapy and outcomes in acute respiratory failure: an observational pilot project. Journal of Critical Care, v. 25, n. 2, p. 254-262, jun. 2010. 